\title{
Notes on the Diets of Some Amphibians and Reptiles of the St. Vincent and Grenada Banks (Lesser Antilles)
}

Robert Powell ${ }^{1}$ and Robert W. Henderson ${ }^{2}$

${ }^{1}$ Department of Biology, Avila University, Kansas City, Missouri 64145 (robert.powell@avila.edu)

${ }^{2}$ Milwaukee Public Museum, Milwaukee, Wisconsin 53233 (rh@mpm.edu)

$\mathrm{D}$ espite conducting extensive fieldwork on the St. Vincent and Grenada Banks for decades, we discovered that we know little or nothing about something as basic as the diets of a number of frogs and reptiles from those islands. Although we could make inferences based on the known diets of closely related taxa, while working on an upcoming volume on the natural history of the amphibians and reptiles of these island banks, we made an effort to address those shortcomings by examining the stomach contents of small samples of seven species: Grenada Frog (P. euphronides), St. Vincent Frog (Pristimantis shrevei), St. Vincent Tree Anole (Anolis griseus), St. Vincent Bush Anole (A. trinitatis), Earless Wormlizard (Bachia alleni), Smooth-scaled Wormlizard (Gymnophthalmus underwoodi), and Garman's Ground Lizard (Ameiva aquilina).

\section{Methods}

We obtained formalin-fixed specimens preserved in ethyl alcohol from the Natural History Museum, University of Kansas, in Lawrence. We made midventral incisions from pelvic to pectoral girdles, exposed and excised the stomachs, removed, identified to order or family, and counted all prey items. Excised stomachs and all contents were stored in containers marked with each lizard's specimen number.

\section{Results and Discussion}

Frogs (Amphibia: Anura: Strabomantidae)

Pristimantis euphronides (Fig. 1; $\mathrm{N}=12$ ): In six specimens (mean SUL $=23.3 \pm 4.3 \mathrm{~mm} ; 19-31 \mathrm{~mm}$ ) with stomachs that had contents, we found ants (Insecta: Hymenoptera: Formicidae; one in each of 2 stomachs), a roach (Blattodea: Blattidae), a beetle (Coleoptera), and one unidentified arthropod in each of two stomachs. One stomach contained a flower.

Pristimantis shrevei (Fig. 2; $\mathrm{N}=10$ ): In seven specimens (mean SUL $=28.6 \pm 4.3 \mathrm{~mm} ; 23-35 \mathrm{~mm}$ ) with stomachs that had contents, we found one spider (Arachnida: Araneae), ants (Insecta: Hymenoptera: Formicidae; one in each of 2 stomachs), one wasp (Hymenoptera: Vespidae), roaches (Blattodea: Blattidae; 2 very large individuals in each of 2 stomachs), beetles (Coleoptera; 5 individuals in 3 stomachs),

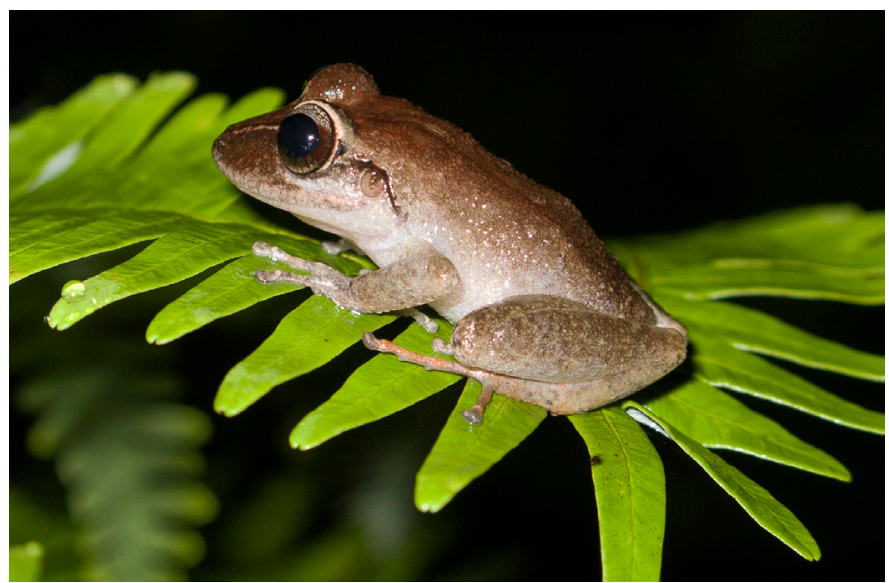

Fig. 1. The endangered Grenada Frog (Pristimantis euphronides) is restricted to higher elevations on Grenada. Photograph (C) Richard A. Sajdak.

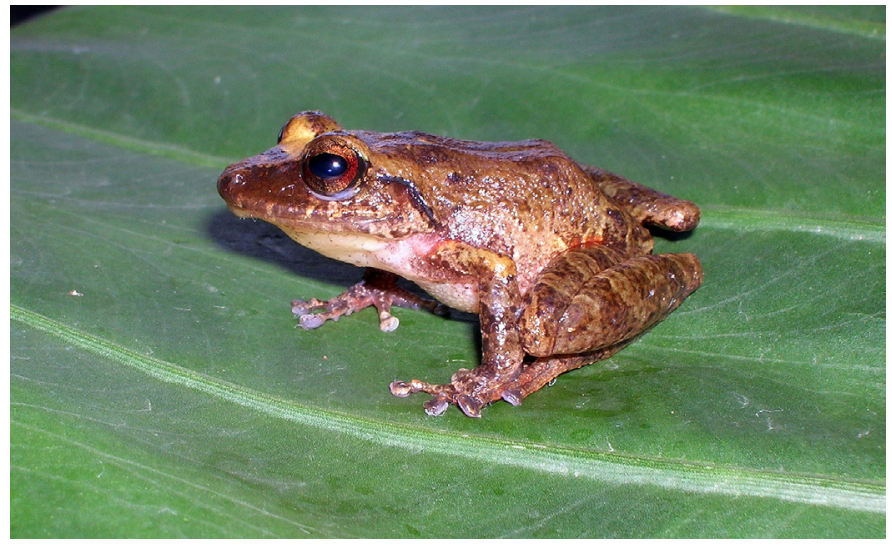

Fig. 2. The endangered St. Vincent Frog (Pristimantis shrevei) is restricted to higher elevations on St. Vincent. Photograph (C) Alondra M. DíazLameiro. 
and a large moth (Lepidoptera). Four stomachs contained leaf fragments or other plant material.

Most frogs are dietary generalists (i.e., Duellman and Trueb 1994) and will eat almost any kind of prey they are capable of consuming. Small frogs, including strabomantids, are largely limited by size to small arthropods. Our small samples support this contention, with 18 individuals of five arthropodan orders represented in 13 stomachs. Because frogs are obligate carnivores, the plant material presumably was adventitiously ingested with prey.

Anoles (Reptilia: Squamata: Dactyloidae)

Anolis griseus (Fig. 3; $\mathrm{N}=13$ ): In the three specimens (all males, $\mathrm{SVL}=55,59$, and $75 \mathrm{~mm}$ ) with stomachs that had contents (two were empty and eight had been previously examined and stomachs were removed), we found ants (Insecta: Hymenoptera: Formicidae; 9 in one stomach and one very large ant in another), one very large roach (Blattodea: Blattidae) alone in one stomach, one moth (or butterfly; Lepidoptera), two beetles (Coleoptera), and one unidentified arthropod. The beetles and the large ant were in one stomach, the nine ants, the lepidopteran, and the unidentified arthropod were in another.

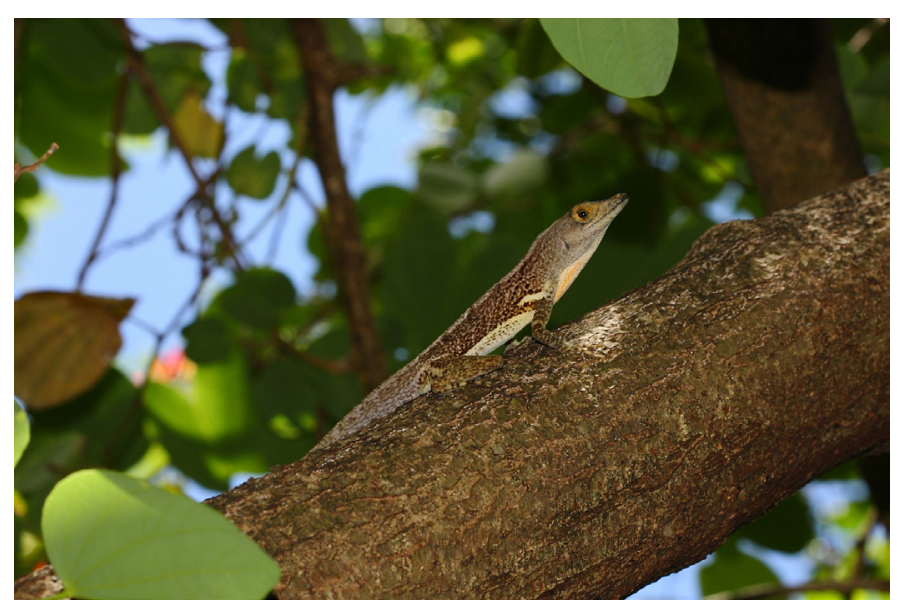

Fig. 3. The St. Vincent Tree Anole (Anolis griseus) is distributed essentially islandwide on St. Vincent and is encountered most frequently in shaded, mesic situations. Photograph (C) Joseph Burgess.

Anolis trinitatis (Fig. 4; $\mathrm{N}=14$ ): In 12 specimens (5 males, mean SVL $=64.0 \pm 4.1 \mathrm{~mm}, 56-67 \mathrm{~mm} ; 7$ females, mean SVL $=45.0 \pm 2.8 \mathrm{~mm}, 41-50 \mathrm{~mm})$ with stomachs that had contents, we found ants (Insecta: Hymenoptera: Formicidae; 20 in 9 stomachs), one fly (Diptera), three crickets (Orthoptera: Gryllidae) in two stomachs, two beetles (Coleoptera; one in each of 2 stomachs), and two unidentified arthropods (one in each of 2 stomachs). One stomach with four ants and an unidentified arthropod also contained five pitted berries.

Although some anoles have been labeled "ant specialists" (e.g., Fite and Lister 1981), especially litter-dwelling mainland

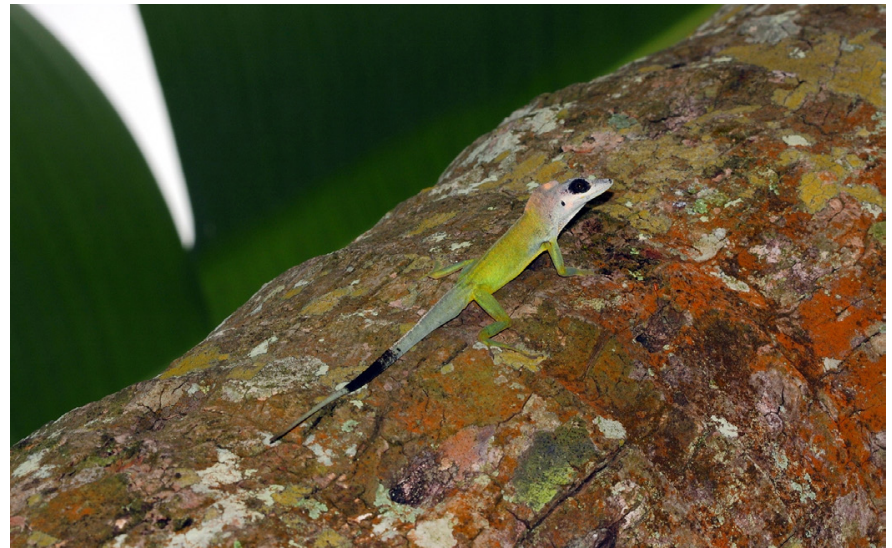

Fig. 4. The St. Vincent Bush Anole (Anolis trinitatis) is essentially ubiquitous on St. Vincent. Male territorial displays include erection of nuchal crests and brightly contrasting colors in what is usually a green lizard. Photograph (C) Joseph Burgess.

species and insular trunk-ecomorphs (sensu Williams 1972), and Pianka (1986) suggested that feeding on social insects like ants is "economically feasible because they normally occur in a clumped spatial distribution and hence constitute a concentrated food supply," we think anoles in general tend to be dietary generalists and species that take a disproportionate number of ants are merely taking advantage of the most abundant food source available. Frugivory is relatively common in anoles, but the fact that the smaller species ate berries contradicts the findings of Herrel et al. (2004), who found that fruit consumption was mediated by large body size.

Wormlizards (Gymnophthalmidae)

Bachia alleni (Fig. 5; $\mathrm{N}=11$ ): In nine specimens (not sexed, but two females with $\mathrm{SVL}=54$ and $52 \mathrm{~mm}$ each contained two shelled eggs; mean SVL of all 9 sampled specimens = $47.1 \pm 5.1 \mathrm{~mm}, 40-54 \mathrm{~mm}$ ) with stomachs that had contents, we found one spider (Arachnida: Araneae), one centipede (Chilopoda: Scolopendridae), one pillbug (Malacostraca:

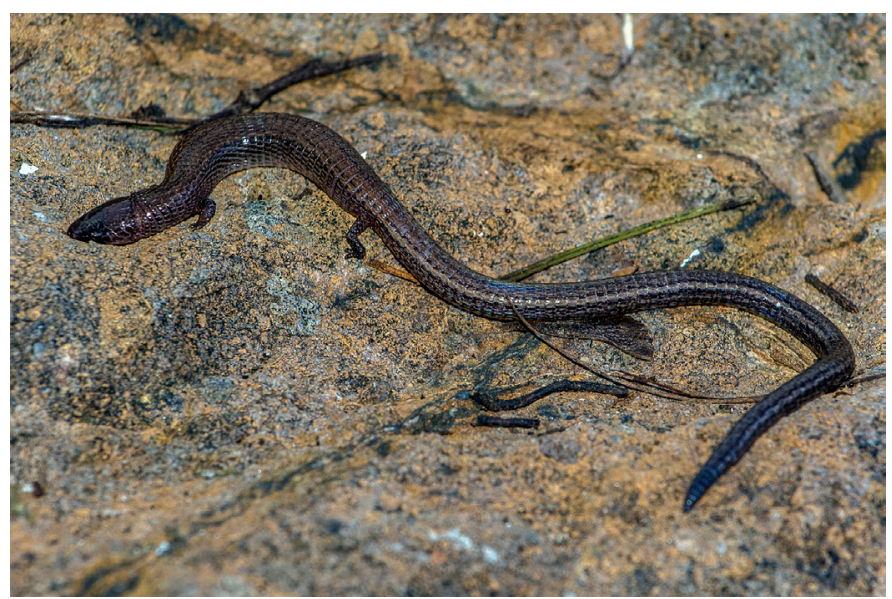

Fig. 5. The Earless Wormlizard (Bachia alleni) is known from Grenada and a number of the Grenadines but has not been recorded on St. Vincent. Photograph (C) Richard A. Sajdak. 
Armadillidiidae), ants (Insecta: Hymenoptera: Formicidae; 5 in 3 stomachs), roaches (Blattodea: Blattidae; 3 in each of 3 stomachs), termites (Insecta: Isoptera; 3 in 2 stomachs), one caterpillar (Lepidoptera), beetles (Coleoptera; one adult and 55 larvae in 6 stomachs, with 22 larvae and the one adult in a single stomach), and at least eight unidentified arthropods in seven stomachs. Two stomachs contained plant material.

Gymnophthalmus underwoodi (Fig. 6; N = 3): None of three specimens had stomachs with contents. Currat (1980) noted that the diet of $G$. underwoodi comprises small insects and their larvae, especially ants and termites.

Malhotra and Thorpe (1999), Germano et al. (2003), and Quinn et al. (2010) indicated that the diet of B. alleni includes small arthropods and their larvae. Our data suggest that these diminutive lizards are quite voracious, not only consuming a wide variety of prey, sometimes in large numbers, but also taking relatively large prey. The centipede in life must have exceeded the 52-mm SVL of the large female that ate it. With no evidence suggesting herbivory, we believe that the plant matter (leaf fragments) was inadvertently consumed.

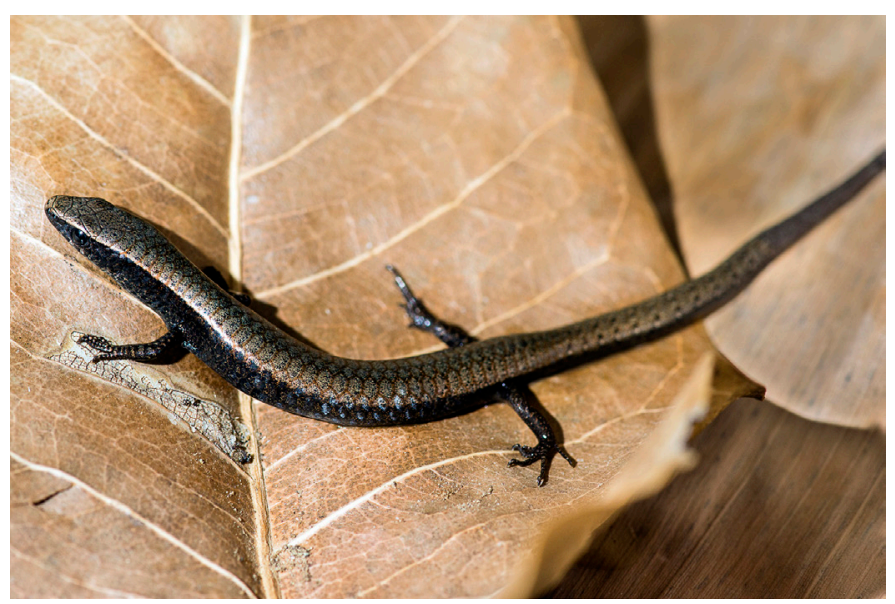

Fig. 6. The Smooth-scaled Wormlizard (Gymnophthalmus underwoodi) is parthenogenetic and consequently an effective colonizer, as only one individual is necessary to establish a population. Unfortunately, none of the lizards in our small sample contained food. Photograph (C) Richard A. Sajdak.

\section{Ground Lizards or Whiptails (Teiidae)}

Ameiva aquilina (Fig. 7; $\mathrm{N}=11$ ): Only three specimens (all males, SVL $=112,116,122 \mathrm{~mm}$ ) had stomachs with contents; these included a spider (Arachnida: Araneae), roaches (Blattodea: Blattidae; 2, one very large, in each of 2 stomachs), and caterpillars (Lepidoptera; 3, one very large, in 2 stomachs). Two of the lepidopteran larvae (including the very large individual), the spider, and a roach were in the stomach of the 122-mm SVL male. Plant material, including a pitted berry, was in the stomach of the 112-mm SVL male that contained no arthropodan prey. The two lizards with arthropodan prey also contained six and 20+ nematodes mixed with ingesta.

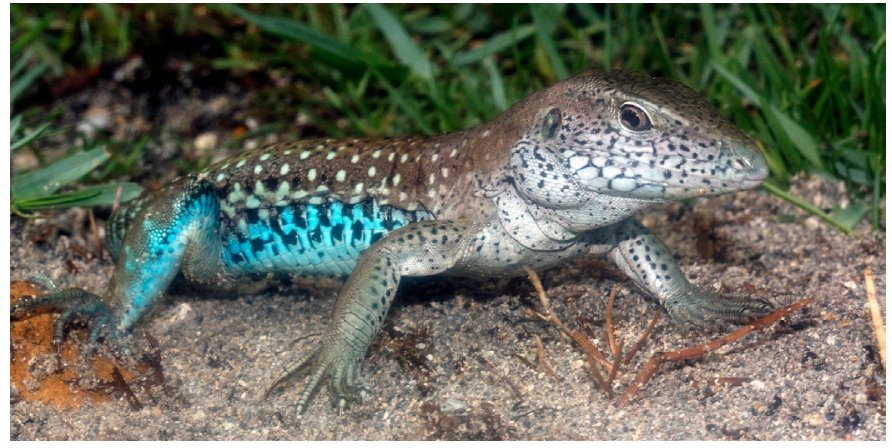

Fig. 7. Garman's Ground Lizard (Ameiva aquilina) occurs on both the St. Vincent and Grenada Banks, but thrives only where the introduced Small Indian Mongoose (Urva auropunctata) is absent or where its presence is reduced in high levels of human activity. Photograph (C) Mel José Rivera Rodríguez.

Whiptails are known to be omnivorous (Schwartz and Henderson 1991), consuming arthropods and small vertebrates (e.g., Simmons et al. 2005), scavenging roadkill (Quinn et al. 2010) and discarded food at a campsite (A. Sánchez Muñoz in Henderson and Powell 2009), and readily taking plant material (Henderson and Powell 2009). Our very limited data appear to support the notion that these lizards have quite catholic diets.

The nematodes were Physaloptera retusa (5 individuals examined from the host with 6 nematodes included one male and 4 females; 10 from the host with $20+$ nematodes included 5 males and 5 females). Physaloptera retusa is widely distributed throughout much of the Americas, but these represent the first records from the Antilles. Previously reported hosts include two South American toads and a variety of lizards, including several teiids, among them the closely related Ameiva ameiva (Bursey et al. 2005). The two lizards with nematodes appeared to be in good condition, suggesting that the latter have a relatively minor effect on their hosts.

\section{Acknowledgements}

Rafe Brown, Curator, and Luke Welton, Collection Manager, University of Kansas Natural History Museum, facilitated the loan of specimens. Stephen Goldberg, Whittier College, identified and sexed samples of the nematodes found in two specimens of Ameiva aquilina.

\section{Literature Cited}

Bursey, C.R., S.R. Goldberg, and J.R. Parmelee. 2005. Gastrointestinal helminths from 13 species of lizards from Reserva Cuzco Amazónico, Peru. Comparative Parasitology 72: 50-68.

Currat, P. 1980. Les Reptiles des Antilles, Aperçu sur les Reptiles Antillais (de Guadeloupe et Martinique Principalement). Centre Départemental de Documentation Pédagogique, Pointe-'a-Pitre, Guadaloupe.

Duellman, W.E. and L. Trueb. 1994. Biology of Amphibians. Johns Hopkins University Press, Baltimore, Maryland.

Fite, K.V. and B.C. Lister. 1981. Bifoveal vision in Anolis lizards. Brain, Behavior and Evolution 19: 144-154. 
Germano, J.M., J.M. Sander, R.W. Henderson, and R. Powell. 2003. Herpetofaunal communities in Grenada: A comparison of altered sites, with an annotated checklist of Grenadian amphibians and reptiles. Caribbean Journal of Science 39: 68-76.

Henderson, R.W. and R. Powell. 2009. Natural History of West Indian Reptiles and Amphibians. University Press of Florida, Gainesville, Florida.

Herrel, A., B. Vanhooydonck, J. Joachim, and D.J. Irschick. 2004. Frugivory in polychrotid lizards: Effects of body size. Oecologia 140: 160-168.

Malhotra, A. and R.S. Thorpe. 1999. Reptiles and Amphibians of the Eastern Caribbean. MacMillan Education Ltd., London, UK.

Quinn, D.P., A.L. McTaggart, T.A. Bellah, E.J. Bentz, L.G. Chambers, H.D. Hedman, R.R. John, D.N. Muñiz Pagan, and M.J. Rivera Rodríguez. 2010. The reptiles of Union Island, St. Vincent and the Grenadines. Reptiles \& Amphibians 17: 222-233.

Schwartz, A. and R.W. Henderson. 1991. Amphibians and Reptiles of the West Indies: Descriptions, Distributions, and Natural History. University of Florida
Press, Gainesville, Florida.

Simmons, P.M., B.T. Greene, K.E. Williamson, R. Powell, and J.S. Parmerlee, Jr. 2005. Ecological interactions within a lizard community on Grenada. Herpetologica 61: 124-134.

Williams, E.E. 1972. The origin of faunas. Evolution of lizard congeners in a complex island fauna: A trial analysis. Evolutionary Biology 6: 47-89.

\section{Appendix}

Specimens examined: Pristimantis shrevei (KU 265445-54; St. Andrew Parish, St. Vincent), P. euphronides (KU 25429-40; St. Andrew Parish, Grenada), Anolis griseus (KU 257969-81; St. George Parish, St. Vincent), A. trinitatis (KU $246733-$ 46; Charlotte Parish, St. Vincent), Bachia alleni (KU 234638-39, 234641-49; St. David Parish, Grenada), Gymnophthalmus underwoodi (KU 315778-80; St. George Parish, Grenada), Ameiva aquilina (KU 246089, 246095, 246099-100, 246102, 246105, 246107, 246111-12, 246114-15; Carriacou, Grenada Grenadines). 